\title{
Studi Perbandingan Hasil Belajar Pendidikan Agama Islam Melalui Penerapan Model Pembelajaran Individual dengan Model Pembelajaran Klasikal
}

\author{
Khoirul Umam ${ }^{1}$, Romdloni ${ }^{2}$, \\ ${ }^{1}$ STKIP Nurul Huda Sukaraja OKU Timur \\ ${ }^{2}$ STKIP Nurul Huda Sukaraja OKU Timur \\ "E-mail: romdloni@stkipnurulhuda.ac.id
}

\begin{abstract}
Abstrak
Tujuan penelitian ini adalah mengetahui ada tidaknya perbedaan hasil belajar mata pelajaran Pendidikan Agama Islam antara siswa yang menerapkan model pembelajaran individual dan menerapkan model pembelajaran klasikal di kelas VII SMP Negeri 1 Buay Madang. Sebagai kegiatan akhir analisis data penelitian dapatlah disimpulkan Pertama: Hasil belajar mata pelajaran Pendidikan Agama Islam siswa yang pembelajarannya menerapkan model pembelajaran individual di kelas VII SMP Negeri 1 Buay Madang adalah sedang dengan nilai rata-rata sebesar 78,57. Kedua: Hasil belajar mata pelajaran Pendidikan Agama Islam siswa yang pembelajarannya menerapkan model pembelajaran klasikal di kelas VII SMP Negeri 1 Buay Madang adalah sedang dengan nilai rata-ratanya 68,15. Ketiga: Terdapat perbedaan hasil belajar mata pelajaran Pendidikan Agama Islam antara siswa yang menerapkan model pembelajaran individual dan menerapkan model pembelajaran klasikal di kelas VII SMP Negeri 1 Buay Madang dengan nilai thitung 7,89 sedangkan ttabel 2,00. Karena thitung 7,89 lebih besar dari harga ttabel $=2,00$ pada taraf signifikan $5 \%$ maka $\mathrm{HO}$ ditolak sedangkan $\mathrm{Ha}$ diterima.
\end{abstract}

Kata kunci: Model Pembelajaran Individual, Model Pembelajaran Klasikal, Hasil Belajar

\section{PENDAHULUAN}

Pembelajaran Pendidikan Agama Islam di SMP Negeri 1 Buay Madang Kabupaten OKU Timur dilaksanakan berdasarkan Kurikulum 2013 edisi revisi 2016 yang menekankan aktivitas belajar siswa. Pada kegiatan pembelajaran guru telah berupaya semaksimal mungkin untuk mengaktifkan siswa melaksanakan seluruh aktivitas belajar melalui kegiatan mengamati, menanya, mengeksplorasi, mengasosiasi, kemudian mengkomunikasikan. Pada pembelajaran Pendidikan Agama Islam di SMP Negeri 1 Buay Madang yaitu guru sering menggunakan model pembelajaran klasikal yang berpegang pada sistem teacher centered learning yaitu pembelajaran berpusat pada guru.

Berdasarkan hasil observasi selama praktik pengalaman lapangan mulai dari tanggal 23 September sampai tanggal 23 November 2017 diperoleh informasi bahwa pembelajaran Pendidikan Agama Islam di SMP Negeri 1 Buay Madang diberikan secara klasikal. Salah satu bentuk pembelajaran klasikal adalah guru memberi penjelasan kepada siswa secara lisan. Bentuk pembelajaran klasikal tersebut dianggap sebagai bentuk pembelajaran yang paling tepat karena guru dapat menyampaikan materi pembelajaran sesuai target kurikulum.

Pembelajaran Pendidikan Agama Islam di SMP Negeri 1 Buay Madang Kabupaten OKU Timur secara umum dapat berjalan secara baik, namun ada beberapa hal yang masih membutuhkan perhatian untuk diperbaiki seperti ada beberapa siswa belum mau terlibat aktif mengikuti seluruh kegiatan pembelajaran. Hasil pengamatan peneliti menunjukkan bahwa hanya terdapat beberapa orang siswa dapat terlibat aktif pada semua kegiatan pembelajaran baik pada tahap mengamati, menanya, mengeksplorasi, mengasosiasi terlebih pada tahap mengkomunikasikan. Pada kegiatan mengamati, menanya, mengeksplorasi, mengasosiasi terlebih mengkomunikasikan, masih terdapat siswa kurang antusias dan terdapat siswa yang sangat dominan selama kegiatan pembelajaran. Siswa terlihat antusias pada kegiatan mengamati, namun hanya sebagian siswa yang aktif dalam 
kegiatan menanya.

Selain permasalahan sebagaimana tersebut, selama kegiatan pembelajaran Pendidikan Agama Islam di SMP Negeri 1 Buay Madang Kabupaten OKU Timur siswa masih terlihat kesulitan dalam mengeksplorasi ataupun melaksanakan berbagai tugas yang diberikan melalui kegiatan mengasosiasi. Masalah juga terjadi ketika kegiatan mengkomunikasikan dimana hanya ada beberapa orang siswa yang aktif mengikuti kegiatan pembelajaran. Pembelajaran Pendidikan Agama Islam di SMP Negeri 1 Buay Madang berjalan kurang efektif dengan indikasi terdapat beberapa orang siswa yang terlihat lesu, tidak bersemangat bahkan terdapat siswa mengantuk. Sebagian siswa pun masih ada yang keluar kelas meninggalkan kegiatan pembelajaran dengan berbagai alasan seperti pergi ke toilet. Beberapa siswa lain terlihat asik bermain dan mengobrol bersama teman sebangku ketika kegiatan pembelajaran berlangsung.

Hasil observasi sebagaimana tersebut kemudian ditindaklanjuti dengan melakukan identifikasi untuk mengetahui penyebab masalah. Hasil identifikasi menunjukkan bahwa permasalahan pada pembelajaran Pendidikan Agama Islam di SMP Negeri 1 Buay Madang disebabkan model pembelajaran yang diterapkan berpusat pada guru. Selama kegiatan pembelajaran kegiatan guru terbatas pada memberikan catatan, menjelaskan materi secara lisan, kemudian memberikan evaluasi. Kegiatan pembelajaran menjadikan siswa merasa bosan, sehingga terdapat siswa kurang konsentrasi mengikuti kegiatan pembelajaran.

Berdasarkan hasil identifikasi masalah pembelajaran Pendidikan Agama Islam di SMP Negeri 1 Buay Madang Kabupaten OKU Timur, maka harus dilakukan berbagai langkah-langkah strategis agar siswa dapat berperan aktif mengikuti kegiatan pembelajaran. Langkah tersebut dapat dilakukan melalui pemilihan model pembelajaran yang sesuai dengan pendekatan saintifik yang telah diterapkan. Oleh karena itu, pada penelitian ini ditawarkan model pembelajaran inovatif kreatif berbasis aktivitas belajar siswa yaitu model pembelajaran individual. Aunurrohman (2011:163) menjelaskan bahwa model pembelajaran individual (the Personalised Model) merupakan model pembelajaran dimana proses pembelajaran dikembangkan dengan memperhatikan minat, pengalaman, dan perkembangan siswa untuk mengaktualisasikan potensi-potensi individualitasnya. Pengertian tersebut menunjukkan bahwa model pembelajaran individual meliputi pengembangan proses individu dan membangun serta mengorganisasikan diri sendiri. Model pembelajaran individual memfokuskan pada konsep diri yang kuat dan realistis untuk membantu membangun hubungan yang produktif dengan orang lain dan lingkungan.

Pembelajaran menggunakan model pembelajaran individual sangat memperhatikan perbedaan individual siswa sehingga pelayanan dapat diberikan sesuai karakteristik siswa. Melalui model pembelajaran individual, seorang guru memahami berbagai perbedaan individual yang dimiliki oleh siswa sehingga guru dapat memberikan pelayanan kepada setiap siswa dengan cara berbeda. Adapun peran guru pada pembelajaran menggunakan model individual dijelaskan Sagala (2011:185) yaitu "Posisi guru adalah membantu siswa, membelajarkan siswa, membantu merencanakan kegiatan belajar siswa sesuai dengan kemampuan dan daya dukung yang dimiliki siswa". Penjelasan tersebut menunjukkan bahwa pada pembelajaran individual, siswa dituntut untuk terlibat aktif mengikuti seluruh kegiatan pembelajaran.

Atas dasar alasan sebagaimana tersebut, maka peneliti menawarkan model pembelajaran individual dan model pembelajaran klasikal untuk diterapkan pada pembelajaran Pendidikan Agama Islam.

\section{METODE/EKSPERIMEN}

Metode penelitian ini jika dilihat dari jenis data serta teknik analisis data yang digunakan termasuk penelitian kuantitatif. Dajan (2008:18) mengemukakan, "Penelitian kuantitatif adalah penelitian yang banyak menuntut penggunaan angka, mulai dari pengumpulan data, penafsiran 
terhadap data tersebut, serta penampilan dari hasilnya". Berdasarkan tingkat eksplanasi, penelitian ini termasuk penelitian komparasi. Sujana (2010:21) menjelaskan pengertian penelitian komparasi sebagai berikut:

Penelitian komparatif merupakan penelitian bersifat membandingkan. Penelitian ini dilakukan untuk membandingkan persamaan dan perbedaan dua atau lebih fakta-fakta dan sifat-sifat objek yang di teliti berdasarkan kerangka pemikiran tertentu. Pada penelitian ini variabelnya masih mandiri tetapi untuk sampel lebih dari satu atau dalam waktu berbeda. Penelitian komparatif adalah jenis penelitian yang digunakan untuk membandingkan antara dua kelompok atau lebih dari suatu variabel tertentu.

Sesuai metode penelitian yang digunakan, maka jenis penelitian yang digunakan adalah eksperimen dengan desain quasi eksperiment. Variabel pada penelitian ini adalah variabe bebas dan variabel kontrol. Variabel bebas penelitian ini adalah hasil belajar Pendidikan Agama Islam siswa yang menggunakan model pembelajaran individual, sedangkan variabel kontrol pada penelitian ini adalah hasil belajar Pendidikan Agama Islam siswa yang menggunakan model pembelajaran klasikal. Hubungan kedua variabel tersebut digambarkan dalam bentuk komparasional yaitu perbandingan. Populasi pada penelitian ini adalah seluruh siswa kelas VII SMP Negeri 1 Buay Madang Tahun Pelajaran 2018/2019 yang berjumlah 84 siswa. Sampel penelitian berjumlah 55 peserta didik yang terbagi dalam dua kelas dan terambil dengan teknik klaster.

Data pada penelitian ini adalah hasil belajar siswa yang diketahui menggunakan instrumen tes. Tes disusun 25 nomor berbentuk pilihan ganda dengan 4 opsi jawaban yaitu a, b, c, dan d. Jika siswa menjawab benar mendapatkan skor 1 dan jika salah mendapatkan skor 0 . Uji instrumen penelitian yang dilakukan adalah uji validitas, uji reliablitas, uji tingkat kesukaran, dan uji daya pembeda soal. Prasyarat analisis data yang dilakukan meliputi uji normalitas dan uji homogenitas. Adapun uji hipotesis yang digunakan adalah uji $t$ polled varian adatau sampel berpasangan. Alasan penggunaan uji $t$ polled varian adalah jumlah $\mathrm{n}_{1} \neq \mathrm{n}_{2}$, data pada penelitian ini berdistribusi normal, serta varian data ( $\sigma 2)$ diketahui (Sugiyono, 2013:197). Pengujian hipotesis menggunakan uji $t$ polled varian dilakukan menggunakan persamaan:

$$
t=\frac{\bar{X}_{1}-\bar{X}_{2}}{\sqrt{\frac{\left(n_{1}-1\right) S_{1}^{2}+\left(n_{2}-1\right) S_{2}^{2}}{n_{1}+n_{2}-2}\left(\frac{1}{n_{1}}+\frac{1}{n_{2}}\right)}}
$$

\section{HASIL DAN PEMBAHASAN}

Masalah diangkat dalam penelitian ini didasarkan pada observasi pendahuluan yang menunjukkan bahwa selama kegiatan pembelajaran Pendidikan Agama Islam di SMP Negeri 1 Buay Madang Kabupaten OKU Timur siswa masih terlihat kesulitan dalam mengeksplorasi ataupun melaksanakan berbagai tugas yang diberikan melalui kegiatan mengasosiasi. Masalah juga terjadi ketika kegiatan mengkomunikasikan dimana hanya ada beberapa orang siswa yang aktif mengikuti kegiatan pembelajaran. Pembelajaran Pendidikan Agama Islam di SMP Negeri 1 Buay Madang berjalan kurang efektif dengan indikasi terdapat beberapa orang siswa yang terlihat lesu, tidak bersemangat bahkan terdapat siswa mengantuk. Sebagian siswa pun masih ada yang keluar kelas meninggalkan kegiatan pembelajaran dengan berbagai alasan seperti pergi ke toilet. Beberapa siswa lain terlihat asik bermain dan mengobrol bersama teman sebangku ketika kegiatan pembelajaran berlangsung.

Berdasarkan hasil identifikasi masalah pembelajaran Pendidikan Agama Islam di SMP Negeri 1 Buay Madang Kabupaten OKU Timur, maka harus dilakukan berbagai langkah-langkah strategis agar siswa dapat berperan aktif mengikuti kegiatan pembelajaran. Langkah tersebut dapat dilakukan melalui pemilihan model pembelajaran yang sesuai dengan pendekatan saintifik yang telah 
diterapkan. Oleh karena itu, pada penelitian ini ditawarkan model pembelajaran inovatif kreatif berbasis aktivitas belajar siswa yaitu model pembelajaran individual dan model pembelajaran klasikal. Secara keseluruhan hasil dari tindakan dapat dideskripsikan sebagai berikut:

\section{A. Hasil Belajar Siswa Menggunakan Model Pembelajaran Individual}

Hasil belajar Pendidikan Agama Islam siswa melalui penerapan model pembelajaran individual diketahui menggunakan instrumen tes. Tes dilaksanakan setelah kegiatan pembelajaran berakhir yaitu pada pertemuan keempat. Instrumen tes disusun sebanyak 20 nomor berbentuk pilihan ganda sesuai materi pembelajaran yang disampaikan guru yaitu shalat berjamaah. Tes diikuti oleh seluruh siswa kelas VII-1 SMP Negeri 1 Buay Madang yang berjumlah 28 orang siswa.

Berdasarkan analisis terhadap hasil tes siswa kelas VII-1 SMP Negeri 1 Buay Madang diketahui bahwa hasil belajar mata pelajaran Pendidikan Agama Islam siswa yang pembelajarannya menerapkan model pembelajaran individual di kelas VII SMP Negeri 1 Buay Madang Tahun Pelajaran 2018/2019 adalah tinggi. Hal tersebut dibuktikan dari hasil tes yang menunjukkan bahwa dari 28 orang siswa terdapat 17 siswa atau $60,71 \%$ yang memperoleh nilai kategori tinggi, 10 siswa atau $35,71 \%$ yang memperoleh nilai kategori sedang dan hanya terdapat 1 siswa atau 3,57\% yang memperoleh nilai kategori rendah dengan nilai rata-rata hasil tes sebesar 78,57 dan standar deviasi sebesar 5,82.

Data hasil tes sebagaimana tersebut menunjukkan bahwa model pembelajaran individual efektif diterapkan pada mata pelajaran Pendidikan Agama Islam. Melalui penerapan model pembelajaran individual hampir seluruh siswa dapat berpartisipasi aktif selama kegiatan pembelajaran sehingga mayoritas siswa memahami materi pembelajaran. Penerapan model pembelajaran individual menjadikan suasana pembelajaran menjadi lebih komunikatif dan berpusat pada siswa. Melalui penerapan model pembelajaran individual siswa dapat memperoleh hasil belajar secara maksimal.

\section{B. Hasil Belajar Siswa Menggunakan Model Pembelajaran Klasikal}

Selain melaksanakan kegiatan pembelajaran di kelas VII-1 SMP Negeri 1 Buay Madang melalui penerapan model pembelajaran individual juga dilakukan pembelajaran di kelas VII-2 SMP Negeri 1 Buay Madang melalui penerapan model pembelajaran klasikal. Kegiatan pembelajaran diikuti 27 orang siswa dan dilaksanakan menggunakan model pembelajaran klasikal. Pembelajaran dilaksanakan 4 kali pertemuan dengan alokasi waktu $8 \times 40$ menit. Pada akhir kegiatan pembelajaran dilakukan evaluasi dengan memberikan soal-soal tes untuk mengetahui hasil belajar siswa setelah penerapan model pembelajaran klasikal. Sesuai hasil uji instrumen, tes yang digunakan berjumlah 20 soal valid berbentuk pilihan ganda. Tes diikuti oleh seluruh siswa kelas VII-2 SMP Negeri 1 Buay Madang yang berjumlah 27 orang siswa.

Berdasarkan analisis hasil tes siswa kelas VII-2 SMP Negeri 1 Buay Madang diketahui bahwa hasil belajar Pendidikan Agama Islam siswa kelas eksperimen 2 yang pembelajarannya menerapkan model pembelajaran klasikal adalah rendah. Hal tersebut dibuktikan dari hasil tes yang menunjukkan bahwa dar 27 orang siswa terdapat 2 siswa atau 7,41\% yang memperoleh nilai kategori tinggi, 12 siswa atau 44,44\% yang memperoleh nilai kategori sedang dan 13 siswa atau $48,15 \%$ yang memperoleh nilai kategori rendah dengan nilai rata-rata hasil tes sebesar $68,15 \%$ dan standar deviasi sebesar 5,66.

Analisis data hasil tes siswa kelas VII-2 SMP Negeri 1 Buay Madang menunjukkan bahwa hasil belajar siswa tergolong rendah. Selain itu dari adanya 13 siswa atau $68,15 \%$ yang memperoleh nilai kategori rendah menunjukkan bahwa pembelajaran kurang dapat berjalan maksimal. Hal tersebut karena pembelajaran dilakukan dengan model pembelajaran klasikal yang menempatkan siswa sebagai objek belajar yang bersikap pasif selama kegiatan pembelajaran. Pemahaman siswa hanya terbatas pada apa yang disampaikan oleh guru tanpa adanya feedback untuk menambah pemahaman serta meningkatkan hasil belajar siswa.

Khoirul Umam ${ }^{1}$, dan Romdloni ${ }^{2}$ 


\section{Hasil Analisis Perbedaan Hasil Belajar Mata Pelajaran Pendidikan Agama Islam Siswa Kelas Eksperimen 1 dan Kelas Eksperimen 2}

Setelah data masing-masing kelas diketahui dan dianalisis, langkah selanjutnya adalah melalukan analisis data untuk mengetahui ada atau tidak perbedaan hasil belajar mata pelajaran Pendidikan Agama Islam antara siswa yang menerapkan model pembelajaran individual dan menerapkan model pembelajaran klasikal di kelas VII SMP Negeri 1 Buay Madang. Analisis dilakukan menggunakan uji t polled varian dilakukan berdasarkan nilai rata-rata serta varian data kedua hasil tes.

Berdasarkan hasil uji $t$ polled varian diperoleh harga $t_{\text {hitung }}$ sebesar $=6,86$. Setelah diketahui

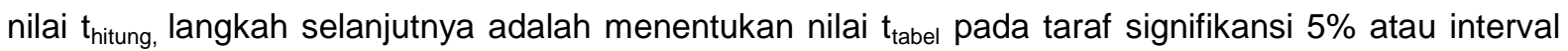
kepercayaan $95 \%$ atau 0,05 dengan $\mathrm{db}=\left(\mathrm{N}_{1}+\mathrm{N}_{2}-2\right)=28+27-2=53$. Pada tabel distribusi $\mathrm{t}$ tidak diketemukan db 53 sehingga pada penelitian ini digunakan nilai tabel untuk df 60 taraf signifikansi $5 \%$ atau interval kepercayaan $95 \%$ atau 0,05 adalah 2,00 . Kriteria pengujian hipotesis penelitian ini adalah terima $\mathrm{H}_{0}$ apabila $-\mathrm{t}_{\text {tabel }} \leq \mathrm{t}_{\text {hitung }}<+\mathrm{t}_{\text {tabel }}$ dan tolak $\mathrm{H}_{0}$ dalam hal lainnya. Oleh karena $t_{\text {hitung }} 6,86$ tidak terletak diantara $-t_{\text {tabel }} \leq t_{\text {hitung }}<+t_{\text {tabel }}$ yaitu $-2,00$ dan $+2,00$ maka $H_{0}$ ditolak, sedangkan $\mathrm{H}_{a}$ diterima. Oleh karena itu dapat disimpulkan bahwa terdapat perbedaan yang signifikan hasil belajar mata pelajaran Pendidikan Agama Islam antara siswa yang menerapkan model pembelajaran individual dan menerapkan model pembelajaran klasikal di kelas VII SMP Negeri 1 Buay Madang.

Analisis data yang telah dilaksanakan menunjukkan bahwa model pembelajaran individual lebih efektif diterapkan pada pembelajaran Pendidikan Agama Islam di kelas VII SMP Negeri 1 Buay Madang. Hal tersebut terbukti dari tabel persentase yang menunjukkan bahwa pada kelompok siswa yang pembelajarannya menerapkan model pembelajaran individual terdapat 17 siswa atau $60,71 \%$ yang memperoleh nilai kategori tinggi dan hanya terdapat 1 siswa atau 3,57\% yang memperoleh nilai kategori rendah. Adapun pada kelompok yang pembelajarannya menerapkan model pembelajaran klasikal hanya terdapat 2 siswa atau $7,41 \%$ yang memperoleh nilai kategori tinggi dan terdapat 13 siswa atau $48,15 \%$ yang memperoleh nilai kategori rendah.

Hasil penelitian menunjukkan bahwa model pembelajaran individual lebih efektif diterapkan pada pembelajaran Pendidikan Agama Islam. Aunurrohman (2011:163) menjelaskan bahwa model pembelajaran individual (the Personalised Model) merupakan model pembelajaran dimana proses pembelajaran dikembangkan dengan memperhatikan minat, pengalaman, dan perkembangan siswa untuk mengaktualisasikan potensi-potensi individualitasnya. Pengertian tersebut menunjukkan bahwa model pembelajaran individual meliputi pengembangan proses individu dan membangun serta mengorganisasikan diri sendiri. Model pembelajaran individual memfokuskan pada konsep diri yang kuat dan realistis untuk membantu membangun hubungan yang produktif dengan orang lain dan lingkungan.

Pembelajaran menggunakan model pembelajaran individual sangat memperhatikan perbedaan individual siswa sehingga pelayanan dapat diberikan sesuai karakteristik siswa. Melalui model pembelajaran individual, seorang guru memahami berbagai perbedaan individual yang dimiliki oleh siswa sehingga guru dapat memberikan pelayanan kepada setiap siswa dengan cara berbeda. Adapun peran guru pada pembelajaran menggunakan model individual dijelaskan Sagala (2011:185) yaitu "Posisi guru adalah membantu siswa, membelajarkan siswa, membantu merencanakan kegiatan belajar siswa sesuai dengan kemampuan dan daya dukung yang dimiliki siswa". Penjelasan tersebut menunjukkan bahwa pada pembelajaran individual, siswa dituntut untuk terlibat aktif mengikuti seluruh kegiatan pembelajaran. Dengan demikian, siswa akan lebih memahami materi pembelajaran dan akan berimplikasi pada pencapaian hasil belajar secara maksimal. 


\section{PENUTUP}

Berdasarkan analisis dan pembahasan hasil penelitian yang telah dilaksanakan dapat disimpulkan sebagai berikut:

1. Hasil belajar mata pelajaran Pendidikan Agama Islam siswa yang pembelajarannya menerapkan model pembelajaran individual di kelas VII SMP Negeri 1 Buay Madang adalah sedang dengan nilai rata-rata sebesar 78,57.

2. Hasil belajar mata pelajaran Pendidikan Agama Islam siswa yang pembelajarannya menerapkan model pembelajaran klasikal di kelas VII SMP Negeri 1 Buay Madang adalah sedang dengan nilai rata-ratanya 68,15 .

3. Terdapat perbedaan hasil belajar mata pelajaran Pendidikan Agama Islam antara siswa yang menerapkan model pembelajaran individual dan menerapkan model pembelajaran klasikal di kelas VII SMP Negeri 1 Buay Madang dengan nilai $t_{\text {hitung }} 6,86$ sedangkan $t_{\text {tabel }} 2,00$. Karena $t_{\text {hitung }}$ 6,86 lebih besar dari harga $t_{\text {tabel }}=2,00$ pada taraf signifikan $5 \%$ maka $\mathrm{H}_{0}$ ditolak sedangkan $\mathrm{H}_{\mathrm{a}}$ diterima.

\section{UCAPAN TERIMAKASIH}

Ucapan terimakasih penulis ditujukan kepada Pengelola STKIP Nurul Huda Sukaraja OKU Timur dan Pengelola Jurnal Al I'tibar

\section{DAFTAR PUSTAKA}

Ambarjaya, Beni S. 2008. Model-model Pembelajaran Kreatif. Jakarta: Praya Media.

Aunurrohman. 2011. Belajar dan Pembelajaran. Bandung: Alfabeta.

Djamarah, Syaiful Bahri. 2010. Strategi Belajar Mengajar. Jakarta: Rineka Cipta.

Madjid, Abdul. 2014. Model-model Pembelajaran. Bandung: Alfabeta.

Purwanto, Ngalim. 2011. Psikologi Pendidikan. Jakarta:Rineka Cipta.

Sagala, Syaiful. 2011. Konsep dan Makna Pembelajaran;Untuk Membantu Memecahkan Problematikan Belajar dan Mengajar. Bandung: Alfabeta.

Sudjana, Nana. 2013. Penilaian Proses dan Hasil Belajar. Jakarta: Algesindo.

Sugiyono. 2013. Dasar-dasar Statistik Pendidikan. Bandung: Alfabeta.

Sukardi. 2013. Metodologi Penelitian Pendidikan:Komptensi dan Praktik. Jakarta: Bumi Aksara.

Tim Penyusun. 2011. Kamus Besar Bahasa Indonesia. Yogyakarta: Balai Pustaka.

Trianto. 2007. Model-model Pembelajaran Inovatif Berorientasi Konstruktivistik. Jakarta: Pustaka Prestasi Publisher. 